Kotyk, A. \& Kleinzeller, A. (1958). J. gen. Microbiol. 20, 197-212

\title{
Movement of Sodium and Cell Volume Changes in a Sodium-Rich Yeast
}

\author{
By A. KOTYK AND A. KLEINZELLER \\ Laboratory for Cellular Metabolism, Biological Institute, Czechoslovak \\ Academy of Sciences, Prague, Czechoslovakia
}

\begin{abstract}
SUMMARY: Sodium-rich yeast was prepared by aerating a yeast suspension in $\mathrm{M}-\mathrm{NaCl}$ for a period of $60 \mathrm{~min}$. This yeast contained then on the average $0.070-0.075 \mathrm{~m}$ equiv. $\mathrm{Na} / \mathrm{g}$. dry wt. On incubating it with glucose, xylose or lactose in water, $0 \cdot 1 \mathrm{M}-\mathrm{KCl}$ or $0 \cdot 1 \mathrm{M}-\mathrm{NaCl}$ it lost some of its sodium, in the last case against an apparent concentration gradient. It appears that this movement of $\mathrm{Na}$ ion is of a diffusion character as evidenced by the effect of temperature, by incubation without metabolizable substrates and by the use of metabolic inhibitors; however, the possibility of an active contribution to this efflux cannot be excluded. The movement of $\mathrm{Na}^{+}$ out of the cell was shown to be connected with considerable changes of cell volume effected above all by changes of osmotic pressure of the medium, sodium being lost as a $0.06 \mathrm{M}-0 \cdot 10 \mathrm{M}$ solution. A discussion of these phenomena is presented.
\end{abstract}

Conway \& Moore (1954) described ionic movements between yeast cells enriched with sodium and their environment, with emphasis laid on the mechanism of transport for $\mathrm{Na}$ and $\mathrm{K}$ ions. It was shown by Conway, Ryan \& Carton (1954) that sodium ions were lost by such yeast into a medium containing either $\mathrm{K}$ ion or no electrolyte, while no net loss of $\mathrm{Na}$ ion was observed on incubating the yeast in $0.1 \mathrm{~m}-\mathrm{NaCl}$ without substrate. It has been shown elsewhere (Kotyk, 1958) that potassium affects phosphorylation processes in yeast cells as evidenced by a rise in the steady-state concentration of inorganic phosphate and by an increased formation of metaphosphate, and that this effect of potassium was more pronounced when the yeast suspension had been aerated for $c .60 \mathrm{~min}$. in $\mathrm{M}-\mathrm{NaCl}$ before the incubation.

In the course of the present experiments the content of $\mathrm{Na}$ and $\mathrm{K}$ in the cells as well as their changes were measured. It was then found that such sodium-rich yeast (hereafter to be designated Na-yeast) lost $\mathrm{Na}$ ions when incubated with glucose, xylose or lactose in distilled water, in solutions of $\mathrm{KCl}$, and even in $\mathbf{0} \cdot \mathbf{1} \mathrm{M}-\mathrm{NaCl}$ when the external concentration of $\mathrm{Na}$ ions was supposed to be higher than that inside the cells. As this phenomenon persisted under conditions when no active transport is assumed to take place (non-metabolizable substrates, $0^{\circ}$ ) a measurement of volume changes of yeast cells was carried out. It was later extended to other conditions of incubation, e.g. under different conditions of aerobiosis, different osmotic pressures of the medium used for washing the yeast pellet and in the presence of several metabolic inhibitors. It was found, in agreement with Conway \& Downey (1950), that yeast cells showed volume changes due to different osmotic pressures of the medium which, however, might possibly be affected by metabolic processes of the cell. Details of these experiments will be described here. 
Evidence will also be presented that the apparent up-hill transport of sodium observed in the Na-yeast may be explained by the considerable volume changes of the cells.

\section{METHODS}

Yeast. In all the experiments described here commercial baker's yeast was used, the properties of which appeared to be satisfactorily normal. It was ascertained several times that its properties corresponded with those of a pure strain of Saccharomyces cerevisiae (R12). When fresh, the baker's yeast used here contained 28-30\% (w/w) dry matter, 0.011-0.023 m-equiv. Na/g. dry wt. and 0.570-0.615 m-equiv. K/g. dry wt. Occasionally it was ascertained that the yeast contained no apparent contamination by other types of yeast or by bacteria.

Preparation of the yeast and incubation procedure. The yeast was aerated before an experiment as a $10 \%(\mathrm{w} / \mathrm{v})$ suspension in $\mathrm{M}-\mathrm{NaCl}$ for $20-120 \mathrm{~min}$., then centrifuged and left standing for $2 \mathrm{hr}$. as a pellet. This period appeared necessary for the attainment of a steady state as evidenced by the values of inorganic phosphate of the organisms (not described in detail here). The pellet was then twice washed in distilled water on the centrifuge and resuspended in the incubation medium used for the specific experiments. The suspension was then placed in a cuvette with a round bottom; a glass tube (a pipette proved to be quite satisfactory) reached near the bottom and served to pass either air or nitrogen into the suspension. Nitrogen was always purified by passing it through two vessels containing freshly prepared alkaline pyrogallol. The cuvette was then placed into a constant-temperature bath when the length of the experiment showed it to be necessary. For shorter experiments, when no kinetic measurements were undertaken, the laboratory temperature $\left(20^{\circ}-21^{\circ}\right)$ was used and a water bath not used.

Sampling. Two methods were used for stopping further metabolic reactions. The first was that of Werkheiser \& Bartley (1957) which uses a silicone oil layer to separate the suspension from the denaturing substance, in our case $10 \%$ trichloroacetic acid. Here the acid was pipetted first, then covered with a layer of silicone $\mathrm{H}$-oil (sp.gr. $=1.05$ ) and finally $1 \mathrm{ml}$. water was placed carefully on top. Then a sample $(1 \mathrm{ml}$.) of the suspension was mixed with the uppermost layer and quickly centrifuged. For a majority of experiments this method of separating of yeast cells from the suspending medium proved satisfactory. However, when inhibitors such as iodoacetic acid and 2, 4-dinitrophenol were used in a $\mathrm{NaCl}$ medium a sudden decrease in $\mathrm{Na}$ content was found for which no explanation can be suggested, save that these inhibitors increased the efficiency with which the silicone oil deprived the cell surface of adsorbed ions. Because of this difficulty as well as those described by Werkheiser \& Bartley (1957) another method of taking samples was preferred. In this method, used by most workers (e.g. Conway \& Moore, 1954), a $3 \mathrm{ml}$. sample of yeast suspension was rapidly centrifuged at a temperature less than $5^{\circ}$, washed with $3 \mathrm{ml}$. ice-cold distilled water and again quickly centrifuged. It was found that virtually no sodium or potassium was lost from the cells by 
this procedure, while the intercellular space was practically devoid of these ions. Both of these methods, however, have the disadvantage of not permitting samples to be taken at very short intervals and thus the kinetic studies of ion movement are only incomplete.

Estimation of sodium and potassium. To estimate the $\mathrm{Na}$ and $\mathrm{K}$ content of the yeast the centrifuged pellet was dissolved in $65 \%$ perchloric acid, placed in a boiling-water bath for $20 \mathrm{~min}$., the volume adjusted to $10 \mathrm{ml}$. with redistilled water and filtered. The actual estimation was carried out on a Zeiss single-cell flame photometer or on a laboratory-built two-cell flame photometer, with $\mathbf{L i}$ as internal standard. Because of the effect of the specific gravity and viscosity of the measured sample on the flow through the atomizer tube, and thus on the amount of liquid dispersed in the flame, care was always taken that the standard solutions had at least approximately the same specific gravity and viscosity as the measured samples by adding equal proportions of perchloric acid to both. The results are expressed in m-equiv./g. dry wt. unless otherwise stated. All measurements reported here were carried out in duplicate or triplicate in each experiment, the values obtained agreeing within $\pm 3 \%$.

Determination of cell volume. The cell volume at different stages of the experiment was determined by filling a haematocrit tube with the suspension, cooling it to $c .0^{\circ}$ to prevent carbon dioxide evolution, and centrifuging for $10 \mathrm{~min}$. at approximately $900 \mathrm{~g}$. Longer centrifugation was avoided because the further packing then obtained was proportional in all cases; moreover, there would then be a risk of carbon dioxide production. The tubes were individually calibrated. 'Volume of cells' is expressed in $\mathbf{~} \mathbf{l} . / 100 \mathrm{ml}$. suspension, the values being obtained by subtracting the inulin space (determined essentially as described by Conway \& Downey, 1950) from the direct haematocrit reading. The value of this space varied between $21-24 \%$ of the pellet volume. The most frequent value of $22 \%$, which is in agreement with the results of the above authors, was used. It was not apparently affected by the decrease in cell volume. The results of duplicate estimations agreed within $\pm 1 \%$.

Measurement of $p H$ value. The $\mathrm{pH}$ value was measured by a glass electrode on a zero-point $\mathrm{pH}$ meter accurate to $0.01 \mathrm{pH}$ unit.

A statistical evaluation of the results of each complete series of experiments was made, their number being far higher than required for statistical significance.

\section{RESULTS}

\section{Changes of sodium and potassium content and of cell volume during aeration of yeast suspension in $\mathrm{M}-\mathrm{NaCl}$}

Unlike Conway \& Moore (1954), who used repeated incubation in sodium citrate with glucose in order to increase the sodium content of yeast cells, a simple aeration in $\mathrm{m}-\mathrm{NaCl}$ was used here and gave similar results. This procedure has the advantage of simultaneously impoverishing the yeast of its endogenous substrate; such a yeast suspension then responds more readily to a glucose addition. Fig. 1 shows the changes of $\mathrm{Na}$ and $\mathrm{K}$ content of yeast 
cells after prolonged aeration in $\mathrm{M}-\mathrm{NaCl}$ as well as the changes in total cell volume. It follows from the results shown in Fig. 1 that the loss of potassium was roughly compensated by the uptake of sodium, while the sharp decrease in volume was obviously due to the hypertonic external medium and probably had no connexion with the ionic shifts examined here.

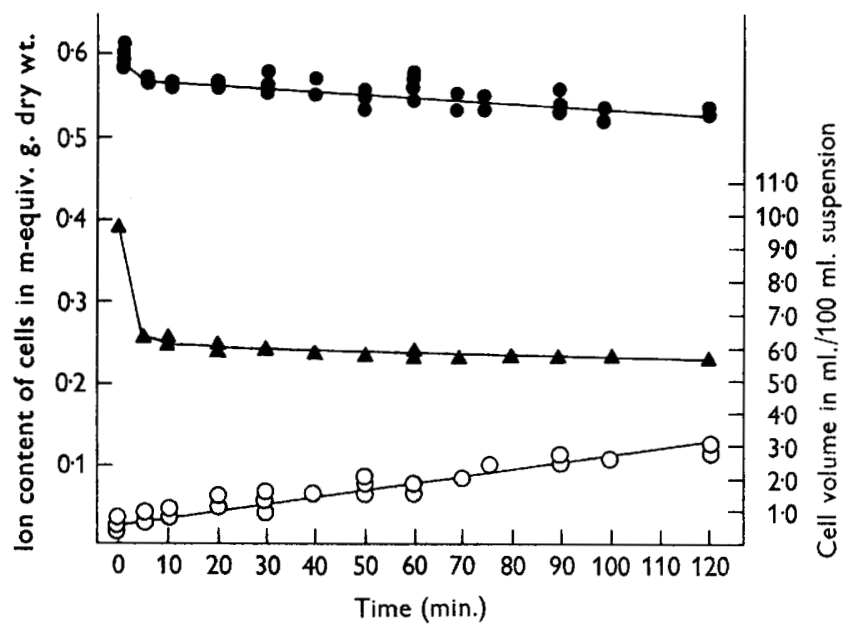

Fig. 1. $\mathrm{Na}$ and $\mathrm{K}$ content and volume of yeast cells during aeration in $1 \mathrm{~m}-\mathrm{NaCl} .10 \%(\mathrm{w} / \mathrm{v})$ suspension of baker's yeast was aerated in $\mathrm{m}-\mathrm{NaCl}$, centrifuged, the pellet left standing for $2 \mathrm{hr}$., twice washed in ten times its volume of distilled water and resuspended in distilled water. Then $\mathrm{Na}$ and $\mathrm{K}$ content was estimated. Volume was determined in samples of aerated suspension directly, using individually calibrated haematocrit tubes.

$\mathrm{K}$ content; $\mathrm{O}, \mathrm{Na}$ content; $\boldsymbol{\Delta}$, cell volume.

It is known that the yeast cells contain approximately twice their dry weight as intracellular water (White, 1954, gives the following figures: $65 \cdot 4 \%$ water, $34 \cdot 6 \%$ dry matter). In our calculations the $29 \%$ value for dry matter will be used as it was determined repeatedly. If we postulate, for the sake of simplicity, that the 'dry matter' of yeast represents one-third of the total cell volume at the outset of the experiment, i.e. say 3 out of 9 volume units, the solution represents 6 volume units. When the total volume is decreased in the course of aeration by 3.3 volume units, i.e. about $37 \%$, the 'cell water' volume is decreased by $55 \%$, assuming that the dry-matter volume does not change. Thus if the $\mathrm{Na}$ content of cells in this procedure is increased approximately twice (cf. Fig. 1 at 20 min. aeration) its concentration in the cell water would increase 4.5 times, assuming an even distribution of sodium in the cell water and that none of it was present in the dry-matter space. However, there is no evidence that the sodium taken up is thus evenly distributed; it may well be (as discussed later) that it is more concentrated in a special part of the cell (cf. Conway \& Downey, 1950). Its concentration would then increase by the same factor as above. On the other hand, if the total cell volume be considered as contractable and penetrable for $\mathrm{Na}$ ions the intracellular sodium concentration would increase $\mathbf{3 \cdot 2}$ times under the same conditions. 


\section{Changes of $N a$ and $K$ content and of cell volume during incubation of the Na-yeast in various media}

Changes of intracellular concentrations of $\mathrm{Na}$ and $\mathrm{K}$ and of cell volume were studied under different conditions of incubation in order to examine the localization of the sodium taken up by the cell and the rate of its movement out of the cell. For most of these experiments yeast was used which had been previously aerated for $60 \mathrm{~min}$. in $\mathrm{M}-\mathrm{NaCl}$ and then centrifuged, left standing for $2 \mathrm{hr}$., washed twice in distilled water and again centrifuged. Its

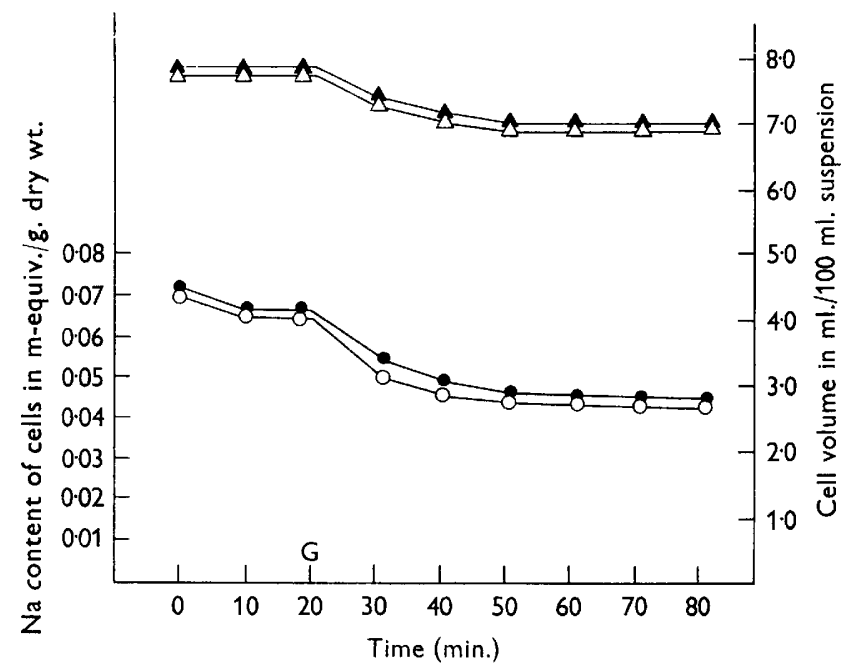

Fig. 2. Na content and volume of Na-yeast cells during incubation in distilled water, aerobically and anaerobically. $10 \%(\mathrm{w} / \mathrm{v})$ suspension in distilled water, at G glucose added to a final concentration of $0.277 \mathrm{M}$. $\mathrm{O}, \mathrm{Na}$ in air;, $\mathrm{Na}$ in nitrogen; $\triangle$, volume in air; $\Delta$, volume in nitrogen.

$\mathrm{Na}$ content was c. 0.070-0.075 m-equiv./g. dry wt. (cf. lower curve in Fig. 1 and subsequent figures, initial values). After washing and resuspending in distilled water the cell volume increased from 5.4 (cf. Fig. 1) to $7 \cdot 9$, which is definitely lower than the original cell volume. Not even a prolonged suspension in water $(24 \mathrm{hr}$.) raised the cell volume to its original value of $\mathbf{9 \cdot 8}$.

Incubation in distilled water. When the Na-yeast was suspended in distilled water it gradually lost some of its sodium, especially under aerobic conditions, the cell volume remaining nearly constant. On addition of glucose to final concentration $0.277 \mathrm{м}(=5 \%, \mathrm{w} / \mathrm{v})$ a loss of sodium was found both in air and in nitrogen, the aerobic process being somewhat faster. The potassium content of the cells did not change under these conditions.

Fig. 2 shows the average content of $\mathrm{Na}$ and volume changes derived from five experiments with incubation in a medium containing no added electrolyte. It can be seen that on addition of glucose the outward movement of sodium down its concentration gradient is accompanied by a decrease in cell volume, the latter being caused probably by an increase of osmotic pressure in the 
medium due to the addition of glucose. From the results obtained it follows that aerobically sodium left the cells as a $0.07 \mathrm{M}$-solution. This value was calculated as follows. The cell volume change between 20 and $50 \mathrm{~min}$. of incubation (cf. Fig. 2) was $7 \cdot 7-6.8=0.9 \mathrm{ml}$; the concomitant change in $\mathrm{Na}$ content was $0.064-0.042=0.022 \mathrm{~m}$-equiv. The concentration of the $\mathrm{Na}^{+}$solution leaving the cells would then be $(0.022 \times 2.9) / 0.9=0.071 \mathrm{M}$ $(2 \cdot 9=$ g. dry matter $/ 100 \mathrm{ml}$. suspension). Similarly, the concentration figures for incubation in $0.1 \mathrm{M}-\mathrm{KCl}$ and $0.1 \mathrm{M}-\mathrm{NaCl}$ were derived from Figs. 3 and 4 , respectively. As far as the sodium efflux is concerned the Na-yeast used here behaved on incubation in water like the Na-yeast prepared by Conway \& Moore (1954; cf. Conway et al. 1954).

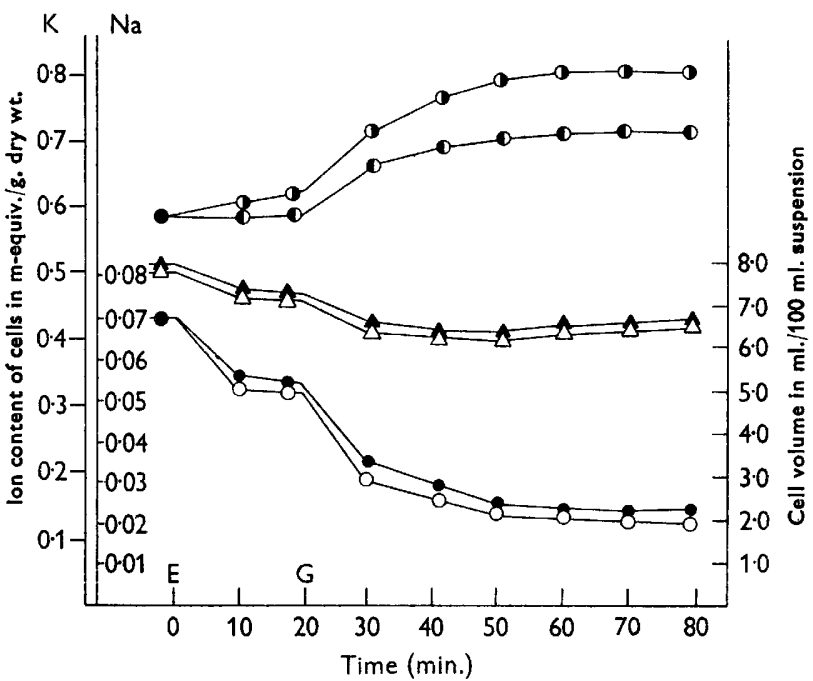

Fig. 3. $\mathrm{Na}$ and $\mathrm{K}$ content and volume of Na-yeast cells during incubation in $0 \cdot 1 \mathrm{M}-\mathrm{KCl}$, aerobically and anaerobically. At $\mathrm{E} \mathrm{KCl}$ was added to a final concentration of $0 \cdot 1 \mathrm{M}$, at $\mathrm{G}$ glucose to a final concentration of $0 \cdot 277 \mathrm{M}$. $\mathrm{O}, \mathrm{Na}$ in air;, $\mathrm{Na}$ in nitrogen; $\mathrm{O}, \mathrm{K}$ in air; $\boldsymbol{O}, \mathrm{K}$ in nitrogen; $\Delta$, volume in air; $\Delta$, volume in nitrogen.

Incubation in $0 \cdot 1 \mathrm{M}-\mathrm{KCl}$. When incubated in $\mathrm{KCl}$ solution the Na-yeast behaved much the same as that of Conway \& Moore (1954), namely, it lost its sodium rather rapidly, particularly when glucose was present. Fig. 3 shows average values of five such experiments, both under aerobic and anaerobic conditions. It follows from the results obtained that sodium left the cells as a $0.10 \mathrm{M}$-solution. This value is higher than that calculated for incubation in water, apparently because potassium ions replaced some of the sodium in the cells. A similar decrease in volume was observed upon adding glucose as when incubating in water. Potassium accumulated in the course of this incubation even in the absence of glucose, as found by Rothstein \& Enns (1946) with normal yeast.

Incubation in $\mathbf{0} \cdot 1 \mathrm{M}-\mathrm{NaCl}$. When the Na-yeast was suspended in water and then $\mathrm{NaCl}$ solution added to a final concentration of $0 \cdot 1 \mathrm{M}$ the yeast regularly took up more sodium by a rapid process, both aerobically and generally also 
anaerobically (see Fig. 4). Simultaneously, a sharp decrease in cell volume of approximately the same magnitude as seen on addition of $\mathrm{KCl}$ of the same molarity was observed. When glucose was added to the same final concentration $(0 \cdot 277 \mathrm{M})$ as in previous experiments, sodium was lost from the cells, both aerobically and anaerobically, while the cell volume decreased further (see Fig. 4), somewhat more than with $\mathrm{KCl}$ (average values of eight experiments). The potassium content under the conditions of incubation with glucose in

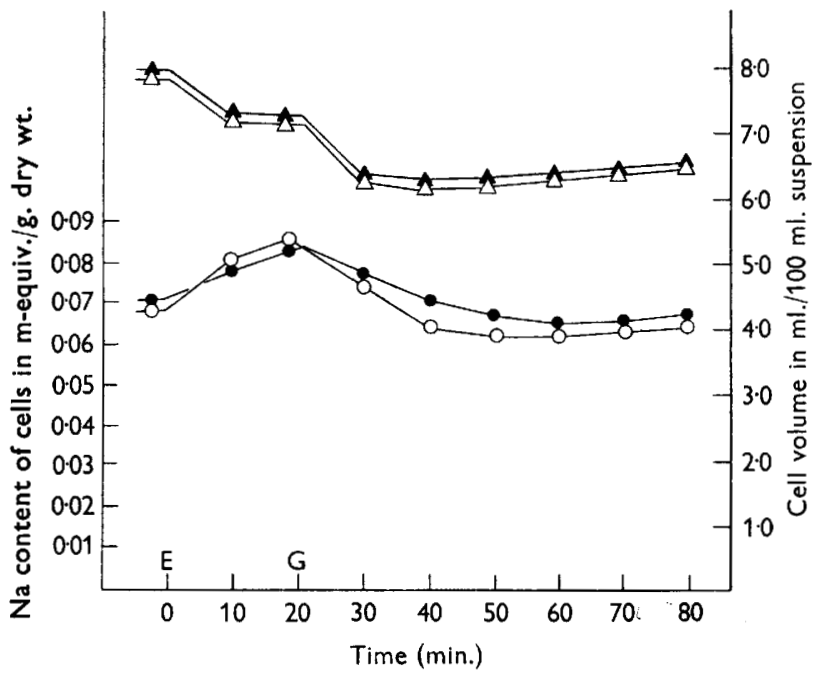

Fig. 4. Na content and volume of $\mathrm{Na}$-yeast cells during incubation in $0 \cdot 1 \mathrm{M}-\mathrm{NaCl}$, aerobically and anaerobically. $10 \%(\mathrm{w} / \mathrm{v})$ suspension in distilled water. At $\mathrm{E} \mathrm{NaCl}$ was added to a final concentration of $0 \cdot 1 \mathrm{M}$, at $\mathrm{G}$ glucose to a final concentration of $0.277 \mathrm{M}$. Symbols as in Fig. 2.

$0 \cdot 1 \mathrm{M}-\mathrm{NaCl}$ did not change at all in $c .70 \%$ of the experiments, for the whole duration of an experiment (30-50 $\mathrm{min}$.), while in the rest the potassium content decreased to a varying extent (by at most $0.022 \mathrm{~m}$-equiv./g. dry wt.). There was no difference in the experimental procedure with yeasts giving these two types of response. At any rate, the change in volume was not affected by this movement of potassium.

On incubation in $0.1 \mathrm{~m}-\mathrm{NaCl}$ with glucose, sodium left the cells apparently as a $0.06 \mathrm{M}$-solution (cf. Fig. 4, between 20 and $50 \mathrm{~min}$.). In other experiments when glucose was added simultaneously with $\mathrm{NaCl}$ to the same final concentrations as above, an increase in $\mathrm{Na}$ content was followed by a gradual decrease, resembling that shown in Fig. 4; the cell volume also decreased to the same final value as there shown.

The experiments illustrated in Fig. 4 show that without substrate sodium was taken up by the yeast cells with a simultaneous decrease in cell volume. This uptake of $\mathrm{Na}$ ion would be most simply explained by the movement of $\mathrm{Na}$ according to its concentration gradient (see later). The decrease in volume observed after the addition of electrolytes appears to be due simply to an 
increased osmotic pressure of the medium and to a consequent movement of water from the yeast cells.

On adding glucose to a final concentration of $0.277 \mathrm{M}$ a further decrease in volume would be expected. Actually, here the volume decrease was gradual and its magnitude was considerably less than would correspond to the molarity of glucose when compared with that of $\mathrm{NaCl}$ or $\mathrm{KCl}$. An explanation of this less-marked decrease may be that suggested by Conway \& Downey (1950) namely that glucose, by being metabolized, may disappear from the external medium rapidly enough to account for a significant decrease of the osmotic gradient. The volume decrease due to glucose was accompanied by a loss of sodium indicating that the cells did not lose water as such but rather as a solution of $\mathrm{NaCl}$. The apparent intracellular concentration of $\mathrm{Na}$ (when only cell water volume is considered, volume changes taken into account, the drymatter volume assumed to be constant and the sodium ions to be in solution) changed on $30 \mathrm{~min}$. of incubation with $0.277 \mathrm{M}$-glucose from 0.039 to $0.031 \mathrm{M}$ in distilled water, from 0.037 to $0.019 \mathrm{M}$ in $0.1 \mathrm{M}-\mathrm{KCl}$, and from 0.058 to $0.057 \mathrm{M}$ in $0.1 \mathrm{M}-\mathrm{NaCl}$ (cf. figs. 2-4, respectively).

A statistical analysis of paired values showed that the differences in the magnitude of loss of $\mathrm{Na}$ after the addition of glucose under aerobic and anaerobic conditions were highly significant (at a $p<0.01$ ); the differences in volume decrease under aerobic conditions and anaerobic conditions were significant at a level of $p<0.05$ (total of eighteen experiments).

\section{The apparent transport of $\mathrm{Na}$ ion against concentration gradient}

While the ion movements observed during incubation of Na-yeast in distilled water and in $\mathrm{KCl}$ seemed to be in agreement with already published data (Conway et al. 1954; Rothstein \& Enns, 1946) the sodium loss as observed during an incubation in $\mathbf{0 . 1} \mathrm{m}-\mathrm{NaCl}$ with glucose was unexpected, as it proceeded seemingly against a concentration gradient of $\mathrm{Na}$, the apparent intracellular concentration of $\mathrm{Na}$ being about $0.025 \mathrm{~m}$-equiv./ml. whole cell (cf. Fig. 4, at G). In order to test whether this process is to be considered as an active transport several types of experiments were carried out.

(1) Na-yeast was incubated with glucose in $0.1 \mathrm{M}-\mathrm{NaCl}$ at $0^{\circ}$ and at $30^{\circ}$. Average results of four such experiments (Fig. 5), indicated that the sodium efflux was more or less of a diffusion character as it proceeded (although at a lower rate) even at a temperature at which active transport processes are considered to be practically negligible (Glynn, 1957; Cort \& Kleinzeller, 1958).

(2) The changes of cell volume and of $\mathrm{Na}$ and $\mathrm{K}$ content of cells on addition of $0.277 \mathrm{M}$-glucose were compared with those resulting from an addition of xylose and lactose to the same molarity. While neither of the latter sugars was metabolized by this yeast, its cell membrane was permeable to xylose, an apparent intracellular equilibrium concentration being reached within $60 \mathrm{~min}$; ; on the other hand, lactose did not enter the cells (Burger, Hejmová \& Kleinzeller, 1958). It was found (see Table 1 ) that the decrease in cell volume, accompanied by a loss of sodium from the cells, occurred also with xylose and lactose, although these sugars cannot serve as a source of metabolic energy. 


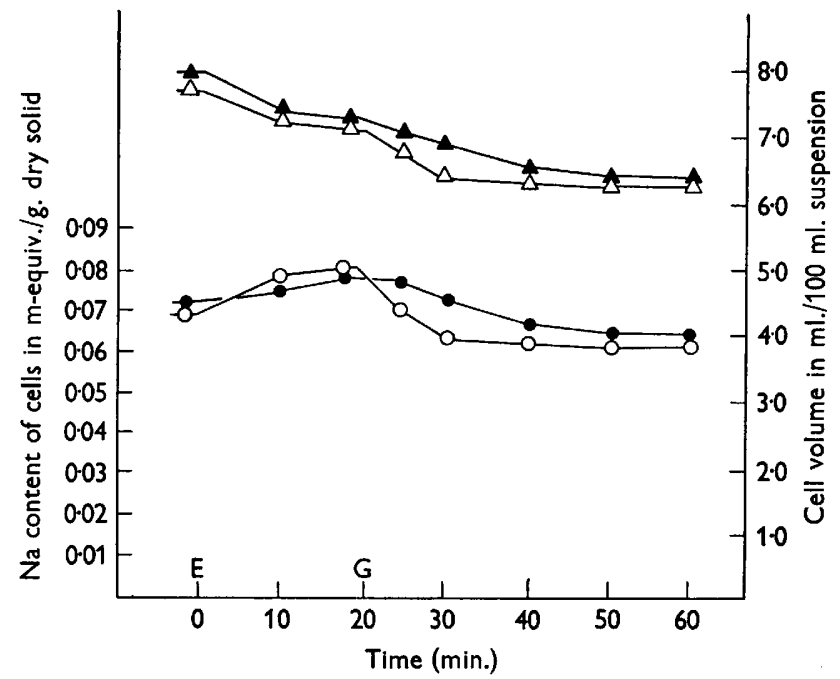

Fig. 5. Na content and volume of $\mathrm{Na}$-yeast cells during incubation in $0 \cdot 1 \mathrm{M}-\mathrm{NaCl}$, aerobically, at $0^{\circ}\left(\bullet, \mathrm{Na} ; \triangle\right.$, volume) and at $30^{\circ}(\mathrm{O}, \mathrm{Na} ; \triangle$, volume). At $\mathrm{E} \mathrm{NaCl}$ was added to a final concentration of $0 \cdot 1 \mathrm{M}$, at $\mathrm{G}$ glucose to a final concentration of $0 \cdot 277 \mathrm{M}$.

Table 1. Cell volume, $\mathrm{Na}$ and $\mathrm{K}$ content of $\mathrm{Na}$-yeast cells on incubation with $\mathbf{0} \cdot \mathbf{2 7 7} \mathrm{M}-$ glucose, xylose and lactose

Aerobic conditions, averages of three experiments

\begin{tabular}{|c|c|c|c|c|c|c|c|c|c|}
\hline \multirow[t]{2}{*}{ Sample taken } & \multicolumn{3}{|c|}{$\mathbf{A}$} & \multicolumn{3}{|c|}{$\mathbf{B}$} & \multicolumn{3}{|c|}{ C } \\
\hline & I & II & III & I & II & III & I & II & III \\
\hline $\begin{array}{l}10 \text { min. after suspending } \\
\text { in water }\end{array}$ & $7 \cdot 8$ & 0.070 & 0.585 & $7 \cdot 8$ & $0 \cdot 069$ & 0.585 & $7 \cdot 8$ & 0.070 & 0.585 \\
\hline $\begin{array}{l}10 \mathrm{~min} \text {. after adding } \\
\mathrm{NaCl} \text { to } 0 \cdot 1 \mathrm{M} \\
(x)\end{array}$ & $7 \cdot 1$ & $0 \cdot 083$ & 0.583 & $7 \cdot 1$ & 0.083 & 0.581 & $7 \cdot 1$ & $0 \cdot 048$ & 0.580 \\
\hline 1 min.) & $6 \cdot 5$ & 0.074 & 0.580 & $6 \cdot 1$ & 0.065 & 0.580 & $6 \cdot 2$ & 0.070 & 0.582 \\
\hline $10 \mathrm{~min}$. & $6 \cdot 2$ & 0.066 & 0.580 & 6.0 & 0.060 & 0.576 & $5 \cdot 8$ & 0.058 & 0.580 \\
\hline 20 min. & $6 \cdot 1$ & 0.064 & 0.580 & $6 \cdot 1$ & 0.063 & 0.580 & $5 \cdot 7$ & $0 \cdot 056$ & 0.580 \\
\hline adding sugar & $6 \cdot 1$ & 0.062 & 0.576 & 6.2 & 0.064 & 0.576 & $5 \cdot 7$ & 0.056 & 0.576 \\
\hline $40 \mathrm{~min}$. & $6 \cdot 2$ & 0.062 & 0.576 & $6 \cdot 5$ & 0.065 & 0.580 & $5 \cdot 7$ & 0.054 & 0.578 \\
\hline $50 \mathrm{~min}$. & $6 \cdot 3$ & 0.064 & 0.580 & $6 \cdot 5$ & 0.065 & 0.580 & $5 \cdot 7$ & 0.054 & 0.578 \\
\hline $60 \mathrm{~min}$. & $6 \cdot 4$ & 0.068 & 0.580 & $6 \cdot 7$ & 0.066 & 0.580 & $5 \cdot 7$ & $0 \cdot 054$ & 0.576 \\
\hline
\end{tabular}

Addition at $(x)$ : A, glucose; B, xylose; C, lactose, always to a final concentration of $0.277 \mathrm{M}$. $\mathrm{I}$, cell volume in $\mathrm{ml}$./100 ml. suspension; II, m-equiv. Na/g. dry wt. III, m-equiv. K/g. dry wt.

The greatest decrease was observed upon addition of lactose, in agreement with the fact that the cellular membrane is impermeable to this sugar, thus preventing an equilibration of the concentrations on both sides of the membrane. Addition of xylose caused the cell volume to decrease as sharply as with lactose; however, the cell volume returned to nearly the initial value in the course of $60 \mathrm{~min}$., thus reflecting the gradual establishment of an osmotic equilibrium. These facts again indicate that the volume decrease was due above 
all to osmotic conditions in the medium as opposed to those in the cell, and that $\mathrm{Na}$ ions were lost as the volume decreased.

(3) $2.5 \times 10^{-5} \mathrm{M}$-dinitrophenol, $5 \times 10^{-4} \mathrm{M}$-iodoacetic acid, and $10^{-3} \mathrm{M}$-sodium azide were used as metabolic inhibitors to provide further information about the character of the sodium loss. The results of three experiments carried out in $\mathbf{0} \cdot 1 \mathrm{M}-\mathrm{NaCl}$ with $\mathbf{0 . 2 7 7} \mathrm{M}$-glucose are summarized in Table 2.

The reason for smaller volume changes with dinitrophenol, as compared with the control, may lie in the fact that this inhibitor increased the glucose consumption by reversing the Pasteur effect and therefore offset the volume decrease caused by hypertonic glucose medium. Iodoacetic acid showed no effect on the decrease of the yeast cell volume; but it is of interest to note that potassium was lost from the cells while little sodium disappeared. Sodium azide produced a sharp decrease in volume, but in relation to this a smaller loss of sodium ions than expected from the results obtained in the presence of glucose either alone or with dinitrophenol. However, the very rapid loss of potassium with azide (and to some extent also with iodoacetic acid) might be responsible for this unexpected behaviour.

All the inhibitors used affected to some extent the decrease in cell volume brought about by the addition of glucose, apparently by interfering either with the mechanism of glucose utilization or with ionic movements. These results by themselves are not conclusive evidence for a direct metabolic influence on the contraction processes of the yeast cell.

(4) Glucose was applied at $0.0277 \mathrm{M}$, which is sufficient to induce metabolic reactions but is relatively unimportant osmotically. The results of this addition, as shown in Table 3 in comparison with $0.277 \mathrm{M}$-glucose, indicate that no significant loss of sodium and no decrease in cell volume was observed under these conditions. It follows, therefore, that the cell volume and $\mathrm{Na}$ content decrease brought about by the addition of glucose is not of a primarily metabolic character.

(5) The results described above can be taken as evidence for the view that the loss of $\mathrm{Na}$ in the presence of glucose, xylose or lactose against an apparent concentration gradient as observed with this $\mathrm{Na}$-yeast is essentially of a passive character. $\mathrm{Na}$ ions move out of the cells as a $0.06 \mathrm{M}$-solution (see p. 203) either because of the shrinkage of the cell (assuming that no higher concentration can exist in the cell), or according to a concentration gradient (assuming that $\mathrm{Na}$ is present at least in some part of the cell at a higher concentration than that of the medium). In order to test which of these assumptions better expresses the above facts and to determine the actual intracellular concentration of $\mathrm{Na}$, the yeast pellet after aeration in $\mathrm{M}-\mathrm{NaCl}$ was washed in different concentrations of $\mathrm{NaCl}$ ranging from 0 to $0.255 \mathrm{M}$. The washing was repeated three times, followed by very rapid suspension of the pellet in ice-cold distilled water, during which time no sodium was lost from the cells, as confirmed specially by using ${ }^{24} \mathrm{Na}$-rich yeast. Table 4 shows that in the course of washing with $\mathrm{NaCl}$ solutions between $0 \cdot 150$ and $0 \cdot 225 \mathrm{M}$ the sodium content of cells was constant, regardless of the $\mathrm{Na}$ concentration in the medium, while sodium was lost from the cells at concentrations below $0 \cdot 150 \mathrm{M}$. This result, obtained in 


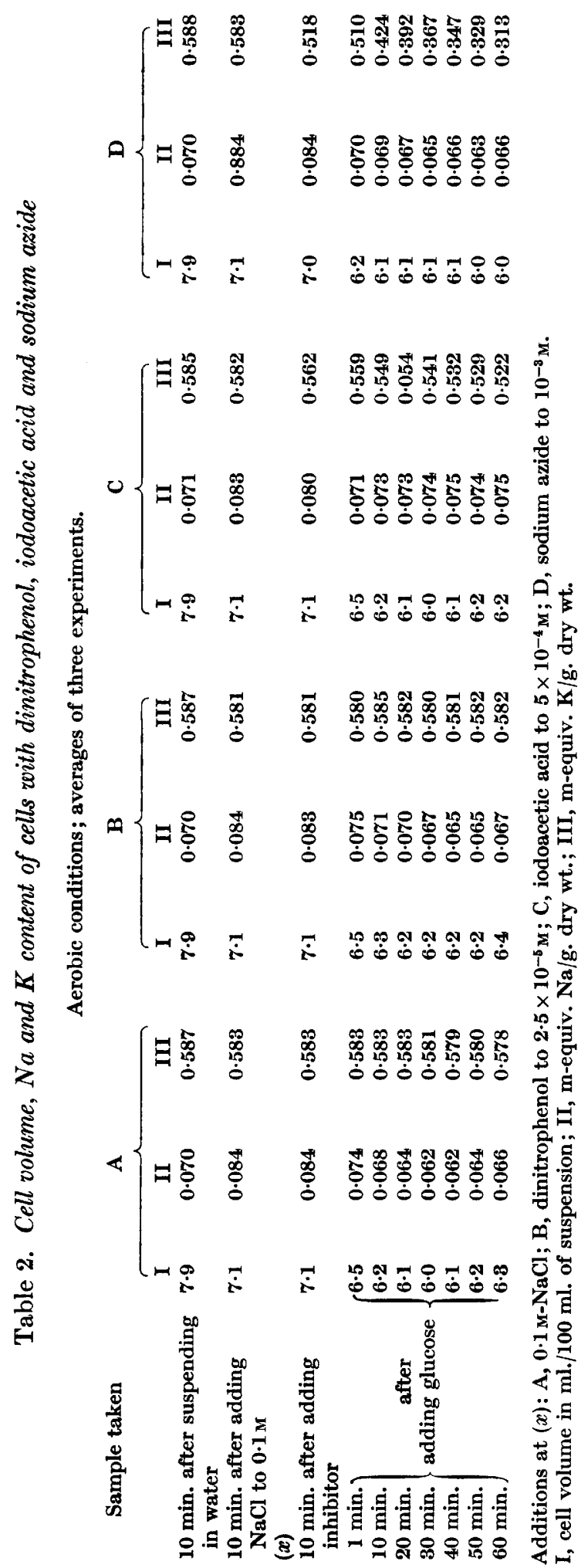


three consecutive experiments, might indicate that $0 \cdot 15 \mathrm{M}$ is the actual maximal $\mathrm{Na}$ concentration that exists in some part of the cell. At the same time it is of interest to return to the fact that a subsequent addition of $\mathrm{NaCl}$ (at concentrations even below $0.15 \mathrm{M}$ without substrate) to a suspension of yeast previously washed with water brought about an increase in the Na content of

Table 3. Cell volume and Na content of Na-yeast cells during incubation with various concentrations of glucose

Aerobic conditions; averages of five experiments.

A

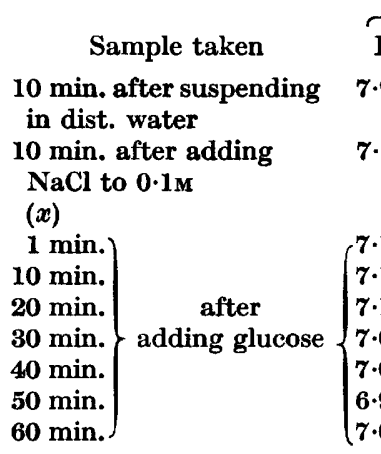

$\overbrace{\substack{\text { I } \\ 7 \cdot 9}}^{0 \cdot 070}$

$7 \cdot 1 \quad 0.082$
B

\begin{tabular}{|c|c|}
\hline I & II \\
\hline $7 \cdot 8$ & 0.071 \\
\hline & 0.082 \\
\hline
\end{tabular}

0.082

0.082

$0 \cdot 081$

$0 \cdot 080$

$0 \cdot 080$

$0 \cdot 080$

0.081

$\begin{array}{ll}7 \cdot 1 & 0 \cdot 083 \\ 7 \cdot 2 & 0 \cdot 084 \\ 7 \cdot 2 & 0 \cdot 082 \\ 7 \cdot 1 & 0 \cdot 082 \\ 7 \cdot 1 & 0 \cdot 082 \\ 7 \cdot 1 & 0 \cdot 082 \\ 7 \cdot 2 & 0 \cdot 083\end{array}$

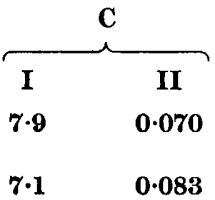

Addition at $(x)$ : A, $0.1 \mathrm{M}-\mathrm{NaCl}$; $\mathrm{B}$, glucose to a final concentration of $0.0277 \mathrm{M}$ (in $0.1 \mathrm{M}$ $\mathrm{NaCl}$ ): $\mathrm{C}$, glucose to a final concentration of $0.277 \mathrm{M}$ (in $0.1 \mathrm{M}-\mathrm{NaCl}$ ).

I, cell volume in ml./100 ml. of suspension; II, m-equiv. Na/g. dry wt.

Table 4. The effect of washing with various concentrations of $\mathrm{NaCl}$ on the $\mathrm{Na}$ content of $\mathrm{Na}$-yeast cells

In m-equiv. $\mathrm{Na} / \mathrm{g}$. dry wt. after triple washing following $60 \mathrm{~min}$. aeration in $1.0 \mathrm{M}-\mathrm{NaCl}$. Average values of three experiments.

$\begin{array}{cc}\text { Molarity of NaCl } & \\ \text { used for washing } & \text { Na content } \\ 0 & 0 \cdot 068 \\ 0 \cdot 025 & 0 \cdot 070 \\ 0.050 & 0.075 \\ 0.075 & 0 \cdot 080 \\ 0 \cdot 100 & 0.082\end{array}$

$\begin{array}{cc}\text { Molarity of NaCl } & \\ \text { used for washing } & \text { Na content } \\ 0.025 & 0.084 \\ 0.150 & 0.085 \\ 0.175 & 0.085 \\ 0.200 & 0.085 \\ 0.225 & 0.085\end{array}$

the cells (see Fig. 4). The increased $\mathrm{Na}$ content, however, never exceeds the value $\mathbf{0 . 0 8 5} \mathrm{m}$-equiv./g. dry matter, which is also the maximum $\mathrm{Na}$ content remaining in the cells after washing (cf. Table 4 , at $0 \cdot 150 \mathrm{M}-\mathrm{NaCl}$ and higher). It is impossible at present to offer an explanation of this effect, but it seems likely that the process of washing in water removes $\mathrm{Na}$ ions from peripheral parts of the cells (possibly the Na space of Conway \& Downey, 1950) or from the surface, which would then become unsaturated as to $\mathrm{Na}$. The added $\mathrm{NaCl}$ would then tend to saturate the surface or peripheral parts, possibly by adsorption. Such a view appears to be of interest because it has been found in further experiments, not described in detail here, that the apparent concentration of 
$\mathrm{Na}$ in and on the yeast cells after aeration in $\mathrm{M}-\mathrm{NaCl}$ and subsequent centrifugation (allowing $30 \%$ for the intercellular space at $500 \mathrm{~g}$ ) amounted to $\mathbf{0} \cdot \mathbf{6} \mathrm{M}$.

In conclusion, from the above set of experiments it may be said that the osmotic component involved in the movement of sodium ions and water appears to play a major role. The explanation is assumed to be that $\mathrm{Na}$ is present in some part of the cell at a concentration higher than in the outside medium, probably at a concentration $0 \cdot 15 \mathrm{M}$. There are indications, however,

Table 5. Volume changes of Na-yeast after passing air into an anaerobic yeast suspension

In $\mathrm{ml} . / 100 \mathrm{ml}$. of suspension; average values of three experiments.

\begin{tabular}{|c|c|c|}
\hline Sample taken & $\mathbf{A}$ & $\mathbf{B}$ \\
\hline $\begin{array}{l}10 \text { min. after suspending in } \\
\text { water }\end{array}$ & $\begin{array}{l}7 \cdot 9 \\
\text { water } \\
\text { added }\end{array}$ & $\begin{array}{c}8 \cdot 0 \\
\text { glucose to } 0 \cdot 277 \mathrm{M} \\
\text { added }\end{array}$ \\
\hline $\begin{array}{l}10 \text { min. after adding water } \\
\text { (glucose) }\end{array}$ & $8 \cdot 1$ & $7 \cdot 2$ \\
\hline $\begin{array}{l}20 \text { min. after adding water } \\
\text { (glucose) }\end{array}$ & $8 \cdot 3$ & $6 \cdot 7$ \\
\hline $10 \mathrm{~min}$. ) & $7 \cdot 8$ & $6 \cdot 7$ \\
\hline after passing air & $7 \cdot 8$ & $6 \cdot 7$ \\
\hline into the suspension & $7 \cdot 9$ & $6 \cdot 9$ \\
\hline $40 \mathrm{~min}$. & $8 \cdot 0$ & 6.9 \\
\hline $50 \mathrm{~min}$. & $8 \cdot 0$ & $7 \cdot 0$ \\
\hline
\end{tabular}

that the volume decrease may also be due to other factors. Besides the effect of inhibitors this is shown by the observation that the cell volume decreased somewhat (Table 5) when air was passed into an anaerobic yeast suspension without substrate; metabolic energy produced in endogenous respiration may be responsible for this volume decrease.

The observed volume changes appear to have no connexion with the loss of hydrogen ions, as these leave the cells very rapidly when even a relatively small amount of glucose is added (Conway \& Brady, 1950) while the volume does not decrease (cf. Table 3). Similarly, the movement of potassium seems to have no general connexion with volume changes.

From microscopical inspection there was no apparent morphological change either in general appearance or in the size of various cell structures before and after addition of glucose.

\section{DISCUSSION}

From the results of other authors (e.g. Conway \& Downey, 1950) it appears that yeast cells undergo volume changes corresponding to the external osmotic pressure. It has been shown in the present work that this holds true in an even greater degree for the Na-yeast used here. The magnitude of this osmotic adjustment seems to be affected by several factors. Thus it follows from the application of glucose, xylose and lactose, as well as from the comparison of 
anaerobic and aerobic cell volumes, that the expected decrease in volume due to osmotic pressure can be slowed down and diminished when the substance which causes the increase of osmotic pressure is taken up by the cell from the medium. This might be one explanation of why the cell volume decreases less anaerobically than aerobically, the anaerobic utilization of glucose being higher than the aerobic one. Perhaps for the same reason the decrease in volume with glucose is less in $\mathrm{KCl}$ than in $\mathrm{NaCl}$ (Rothstein \& Enns, 1946), with dinitrophenol than without it, and with glucose than with xylose, or especially with lactose, in the first few minutes after addition. However, metabolic processes also may be involved in the cell volume changes. Thus the difference in cell volume under aerobic and anaerobic conditions (cf. Figs. 2-4) might be explained by metabolic factors, as well as the more rapid decrease in cell volume observed at higher temperatures (cf. Fig. 5). Similarly, the effect of inhibitors seems to be of a more complex nature and some of their effects might be attributed to metabolic influences, e.g. the decrease in cell volume with iodoacetic acid and sodium azide which appears to be associated with a flow of $\mathbf{K}$ ion from the cell.

In connexion with the decrease in cell volume it is of interest to note that when yeast has been previously enriched with sodium by a simple aeration in sodium chloride, sodium is lost from the cells against an apparent concentration gradient. It was shown above that the loss of sodium from the cells brought about by the addition of a sugar such as glucose (metabolized), xylose (not metabolized but penetrating into the yeast cell) or lactose (not metabolized and not penetrating into the yeast cell) proceeds under conditions when it can be assumed that no active transport takes place. It was therefore concluded that the loss of sodium associated closely with a decrease in cell volume is of a passive character. Two possible explanations for this loss of sodium offer themselves.

Firstly, if there exists a maximum concentration of sodium in the total cell water which cannot be exceeded, sodium is lost from the cells as a solution when the cell volume decreases. In this way its internal concentration could be maintained if the outgoing solution were of the same concentration as the sodium 'solution' in the cell. The results presented above do not contradict this view : $0.06 \mathrm{M}$ is roughly the concentration of $\mathrm{Na}$ ion solution lost by the cells (cf. p. 203) and $0.06 \mathrm{M}$ is about the calculated concentration of sodium in the cell water (cf. p. 204). However, Conway \& Moore (1954) reached a far higher concentration of $\mathrm{Na}^{+}$in their $\mathrm{Na}$-yeast (as much as $\mathbf{0 . 2}$ m-equiv. $\mathrm{Na} / \mathrm{g}$. wet yeast).

The second explanation is concerned with the possibility that some or all of the sodium, taken up by the cells in the course of aeration in $\mathrm{M}-\mathrm{NaCl}$, is localized in only a part of the cell, where its concentration would be correspondingly higher than the above-mentioned value of $0.06 \mathrm{M}$. It appears that the results presented above can be better reconciled with such explanation. As shown by experiments (Table 4) the sodium concentration in this part of the cell may be as high as $0.15 \mathrm{M}$. From this special compartment sodium ions would leak, either according to their concentration gradient or again due to the cell volume decrease if a certain maximum concentration 
cannot be exceeded. It is difficult to test by which of the last-named ways sodium ions actually leave the cells. In distilled water sodium is lost from the cells obviously by simple diffusion according to its concentration gradient; however, when $\mathrm{NaCl}$ solution is used as medium the picture is distorted by the fact that the cell volume decreases at the same time; furthermore, when a more concentrated solution of $\mathrm{NaCl}$ is used than that employed for washing the yeast additional sodium is taken up by the cells, possibly by adsorption on the cell surface or by simple diffusion into a peripheral 'sodium' (?) space.

If it be postulated that all the sodium taken up in the course of the preliminary aeration in $\mathrm{M}-\mathrm{NaCl}$ is localized in the above-mentioned special site in the cell at a concentration of $0.15 \mathrm{M}$, the size of this site can be estimated in the following way. Yeast takes up, in the course of $60 \mathrm{~min}$. of aeration, on the average $0.065 \mathrm{~m}$-equiv. $\mathrm{Na} / \mathrm{g}$. dry wt., i.e. $0.026 \mathrm{~m}$-equiv. $\mathrm{Na} / \mathrm{ml}$. total cell volume after aeration and washing. The sodium content of the yeast cell increases further to at most $\mathbf{0 . 0 8 5} \mathrm{m}$-equiv./g. dry wt. when it is suspended in $0 \cdot 1 \mathrm{M}-\mathrm{NaCl}$, which represents $0.035 \mathrm{~m}$-equiv. $\mathrm{Na} / \mathrm{ml}$. total cell volume at that stage of incubation (cf. Fig. 4 at 20 min.). Therefore, for the concentration of $\mathrm{Na}$ inside the cell to reach the value of $0.15 \mathrm{M}$ it must be concentrated in a volume representing about $23 \%$ of total cell volume just before glucose addition. Now, as the cell water volume at this stage is assumed to occupy on the average $59 \%$ of the total volume (the dry-matter volume is considered not to decrease in the course of aeration and incubation; for values see Table 3 , column 1) the Na-space would amount to $39 \%$ of the cell water volume. As it is probable that the Na-space decreased in parallel with the decrease of the remaining cell water volume, the Na-space would amount to about $25 \%$ of the total cell volume after aeration and washing and to about $28 \%$ of the total cell volume prior to the aeration. This value is about three times as high as that given by Conway \& Downey (1950) for an outer metabolic space of the cell, but is significantly lower than the apparent 'sugar space' found by Burger et al. (1958) to represent about $55 \%$ of the original normal yeast cell volume as determined by estimating the amount of a non-metabolized sugar (galactose) inside the cell after equilibration with a galactose-containing medium.

However, there is no way of testing at present whether all the sodium taken up in the course of aeration is localized in the assumed special compartment. If only some part of it is located there the size of this cell space will be smaller and may well approach the value given by Conway \& Downey (1950). As a matter of fact by assuming a smaller $\mathrm{Na}$-space freely penetrable by $\mathrm{Na}$ ions the partial loss of sodium after washing with water and its additional uptake after adding $\mathrm{NaCl}$ to the yeast can be explained.

The suggested explanations of the results obtained may have to be modified when more data are to hand (particularly through the introduction of faster methods of measuring the cell volume and by extending the study to subcellular particles), but they present a point to be considered in drawing conclusions about transport phenomena in yeast cells.

Our thanks are due to Miss J. Sevců for skilful technical help. 


\section{REFERENCES}

Burger, M., Hejmová, L. \& Kleinzeller, A. (1959). Transport of some mono- and disaccharides into yeast cells. Biochem. J. 71, 233.

Conway, E. J. \& Brady, T. G. (1950). Biological production of acid and alkali. Biochem. J. 47, 360.

Conway, E. J. \& Downey, M. (1950). An outer metabolic region of the yeast cell. Biochem. J. 47, 347.

Conway, E. J. \& Moore, P. T. (1954). A sodium yeast and some of its properties. Biochem. J. 57, 523.

Conway, E. J., Ryan, H. \& Carton, E. (1954). Active transport of sodium ions from the yeast cell. Biochem. J. 58, 158.

Cort, J. H. \& Kueinzeller, A. (1958). The effect of temperature on the transport of sodium and potassium by kidney cortex slices. J. Physiol. 142, 208.

GLYNn, I. M. (1957). The ionic permeability of the red cell membrane. Progr. Biophys. $8,241$.

Kотук, A. (1958). The influence of $\mathrm{K}^{+}$on phosphorylation processes in Saccharomyces cerevisiae. Biokhimija, 23, 737.

Rothstein, A. \& Enns, L. H. (1946). The relation of $\mathrm{K}$ to carbohydrate metabolism in baker's yeast. J. cell. comp. Physiol. 28, 231.

WerkHeiser, W. C. \& BARTLEY, W. (1957). The study of steady state concentrations of internal solutes of mitochondria by rapid centrifugal transfer to a fixation medium. Biochem. J. 66, 79.

White, J. (1954). Yeast Technology. London: Chapman and Hall.

(Received 22 July 1958) 